\title{
biló \\ Evaluation of Ship Profiles in Istanbul Port Region with Two-Stage Clustering Analysis
}

\author{
Firat Bolat ${ }^{1 *}$
}

\begin{abstract}
The increase in industrial production and thus world trade has also increased the significance of the maritime sector further. Ports are of strategic importance as trade points in this sector. Strategies for reducing maritime transport costs and waiting-periods for the ships in ports cause increased competition between ports. Clustering theory focuses on the industries of certain regions defined as industrial zones. Most of the research on the maritime industry focuses primarily on its structure and economic impacts on national economies, without providing detailed information on particular economic and technological activities at the regional level. However, successful clusters are seen as means for regional and national growth. In this context, a two-stage clustering analysis was conducted, considering the different characteristics of the ship profiles that visited the area covering three administrative ports (Ambarl1, Tuzla, İstanbul) of the Istanbul Port Region. The clustering was made according to the type and flags of the ships that visited Istanbul Port Region, the ports they visited and the length of stay in the ports they visited. The clustering characteristics of the Istanbul Port Region were extracted with regard to the ship profiles.
\end{abstract}

Keywords: Clustering Analysis, Maritime, Transportation, Istanbul Port Region

${ }^{1}$ Address: Istanbul Technical University, Maritime Faculty, Department of Marine Engineering, Istanbul, Turkey

*Corresponding author: bolatf@itu.edu.tr

Citation: Bolat, F. (2020). Evaluation of Ship Profiles in Istanbul Port Region with TwoStage Clustering Analysis. Bilge International Journal of Science and Technology Research, 4 (Special Issue): 33-39.

\section{INTRODUCTION}

Clustering is a technique that is used to capture the similarities and differences between homogenous groups of individuals (Saneinejad and Roorda, 2009), institutions, organizations etc. with regard to different characteristics of those groups. The goal of clustering is to group data points that are close (or similar) to each other and identify such groups in an unsupervised manner (Jain et al., 2019).

In economics, on the other hand, clustering theory focuses on the industries of certain regions, which are defined as industrial zones. The theory states that industries concentrating at specific regions create numerous advantages such as less competition and greater profits. The constant presence of an unchanging customer base guarantees their business and a stable income, and the constant presence of suppliers also means low cost for companies (Guadalupe Arredondo-Hidalgo and Guadalupe Covarrubias Gardia, 2019).
In other words, in the last two decades, cluster theory has been defined and adopted as a means to understand better the economic activities in service and knowledge-based regional economies. Clustering generates efficiency, reflects innovation capabilities, and involves the transmission of new business information. This is one of the most important reasons for the tendency of industries to maintain a clusterlike style. The concept of the industrial cluster played an active role in the economy and defined it as a decisive feature in formulating business strategies and industrial policies (Zhang and Lam, 2013).

There are three reasons for cluster development. First, companies or organizations operate at a higher efficiency level. This means that companies or institutions in clusters react more quickly because they are isolated. Second, companies or institutions that work closely with customers or other firms in the clusters create more ideas and put an intense pressure on innovation. They can reach higher levels of innovation because the cluster environment reduces the cost of testing. Third, the level of start-up tends to be higher 
in clusters and relies more on external suppliers and business partners. The above conditions will reduce the risk of failure as entrepreneurs can rely on local employment opportunities in other companies in the same field (Chang, 2011).

The increase in industrial production and thus world trade has also increased the significance of the maritime sector further. Ports are of strategic importance as trade points in this sector. Strategies for reducing maritime transport costs and waiting-periods for the ships in ports cause increased competition between ports.

Most of the research on the maritime industry focuses primarily on its structure and economic impacts on national economies, without providing detailed information on particular economic and technological activities at the regional level. However, successful clusters are seen as means for regional and national growth. This study investigates the nature of the impact of ship profiles in Istanbul maritime industry and determines the extent, to which these impacts vary according to ports, ship types, flags, ports density and location within a cluster.

Regarding the economic development of the regions, it is observed that there is a close connection between the intensity of the port activity and the economic development of the region in the Marmara Region. In this respect, Izmit Bay and Istanbul ports are the main regions that make up Marmara ports with their industrial facilities. Istanbul Port Area is comprised of Tuzla, Ambarlı, Silivri, Istanbul and Sile ports. When the data obtained from the Istanbul Port Authority is analyzed, it is seen that the ports that make the most commercial contribution to the country are Ambarlı, Tuzla and Istanbul (URL-1).

In this context, a two-stage clustering analysis was carried out considering the different characteristics of the ship profiles that visited the area covering these three ports (Ambarl1, Tuzla, İstanbul) of Istanbul Port Region. In the analysis, clustering was made with regard to the type and flags of the ships that visited Istanbul Port Region, the ports they visited, and the length of stay in the ports they visited. The clustering characteristics of Istanbul Port Region were extracted according to the ship profiles.

\section{MATERIAL AND METHOD}

The main purpose of this study is to examine the various characteristics of the vessels found in the port area of Istanbul, and to categorize them into two groups via twostage clustering analysis for evaluating the differences between the identified groups.

\subsection{Data}

It is aimed at clustering the data set used in the study with regard to the following features:

- Ports of call,

- Flags of the ships,

- Length of stay,

- Types of ships.

There were three different ports of call as Ambarl, Tuzla and Istanbul ports in Istanbul Port Area. The flags of the ships stayed in the harbors were comprised of 29 different countries (Germany, Panama, Portugal, Singapore, Turkey, etc.). The length of stay feature was handles on a day-to-day basis and was of the continuous data type. The types of ships under scrutiny were container / ro-ro, dry, and tanker.

Based on the measurements of the aforementioned features of the vessels stayed in Istanbul Port Area, 6638 separate cases were obtained from the Istanbul Port Authority. This data was first used to determine the frequency distributions for these four variables. As for the type of port, the Ambarl 1 port seems to be the port that provided more data (57.2\%), followed by Tuzla $(31.3 \%)$, and Istanbul port $(18.9 \%)$. Figure 1 presents the flag dispersion as half of the ships $(52.5 \%)$ carrying Turkish flag, and the other half is split to 28 different country flags (varying between $2 \%$ and $9 \%$ ). When the length of stay feature is considered, it is seen that the vessels stayed in the harbor for an average of 1 to 3 days. When ship type is considered, container / ro-ro vessels ranked first in number (57.8\%), dry cargo vessels following them with $31.3 \%$, and tanker type vessels being the third $(10.9 \%)$.

\subsection{Analysis}

After determining the frequency distribution of the aforementioned features, considering the data obtained from the Istanbul Port Authorities, the clustering analysis, in which the ships are grouped according to the relevant characteristics, was conducted. At this stage, a two-stage clustering analysis was used since the variables discussed in section 3.1 were comprised of categorical and continuous variables, since the study handled a large data set, and since the management could automatically determine the optimal number of clusters. In another study conducted by Ceylan et al. in 2017, the same method was implemented in banking sector and set an example for the analysis of this study (Ceylan et al., 2017).

In this study, the main purpose of using two-stage clustering analysis is to determine different groups by gathering the vessels visited Istanbul Port Region in the same cluster, regarding similar characteristics, and to reveal the significance of the variables for the groups. Thus, the port inspector is expected to have prior knowledge and insight, and to make strategic decisions about specific ships in each group by categorizing the ships arriving at the port area into different groups.

The summary result of the two-stage clustering analysis is shown in Figure 2. In the analysis, the clustering quality range was selected as -1 to +1 scale, and the results indicated that the clustering quality obtained is close to 1 , therefore it is "good".

Figure 3 shows cluster distributions that occur regarding the variables. As is seen, the 6638 ships arriving in Istanbul Port Area were divided into two clusters. These two clusters are comprised of 2999 (45.2\%) and 3639 (54.8\%) ships, respectively. Only one of the voyages of the same ship in 2018 was included in the study and other frequencies were excluded from the data set in order to ensure homogeneity. IBM SPSS V.25 provides information about the significance of each variable on the cluster. In the software, variables with significance level 0.80 and above are considered to have a significant effect on the cluster. 

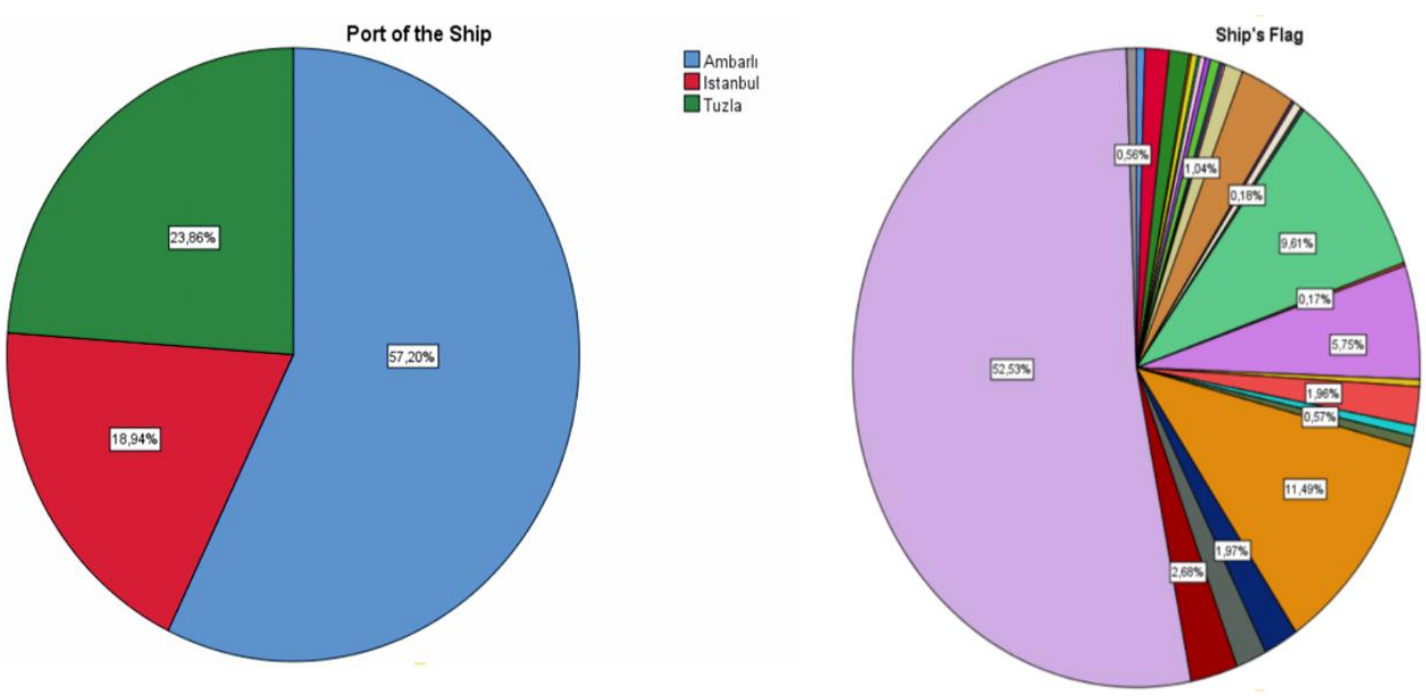

\section{GgERMANY} GANTIGUA EANTIGUAA AID - AZERBANAN G GREAT BRTIAIN G GiBraLtar GALGERIA COMOROS CHINA GDENMARK GNETHERLANDS EENGLAND DIRAN DISRAEL DLIEERIA
RLUEMBOURG
GMLITA GISIE OF DISLE OF MAN IMOLDONA - PALAU - PANAMA - PORTUGAL GINGAPORE DTURKEY gVanuatu
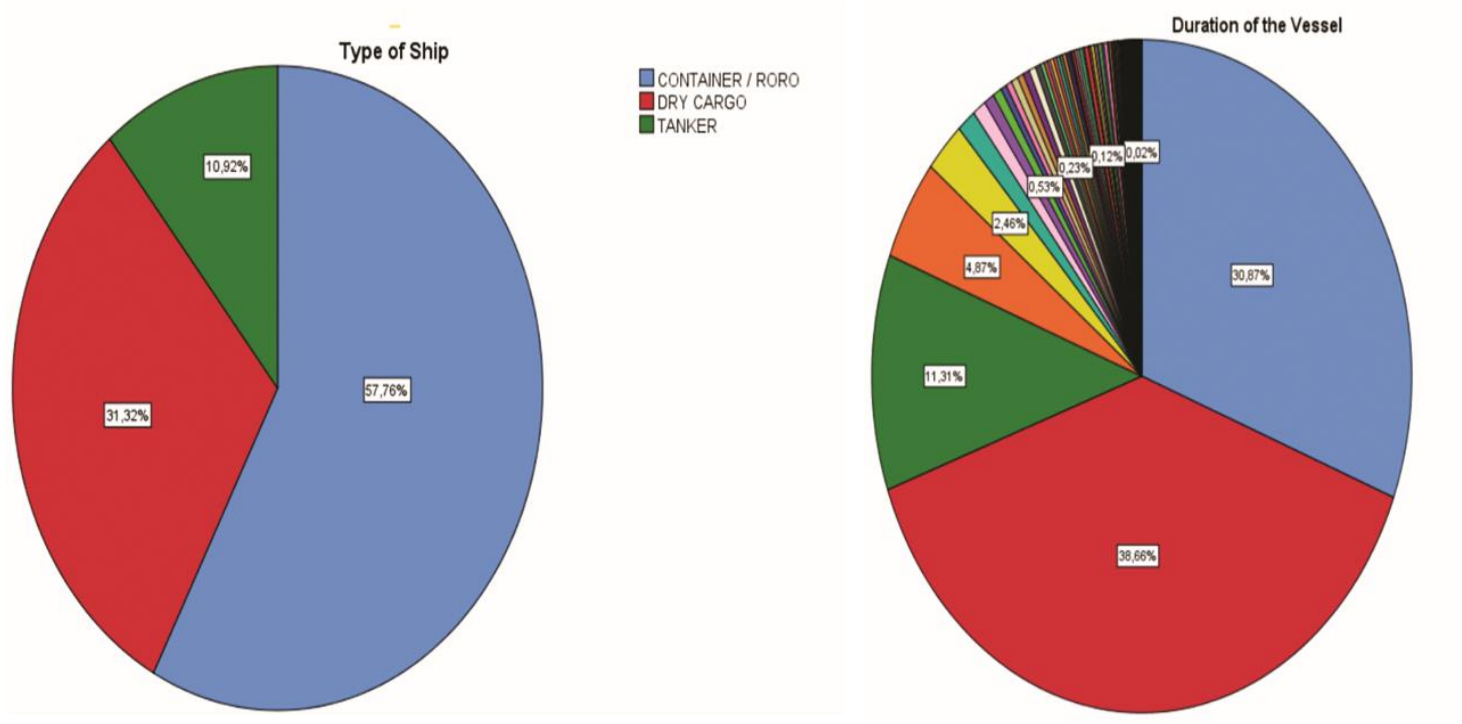

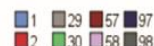

$2-30 \square 58-98$

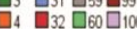

$05-33 \square 61 \square 10$

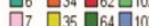

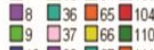

- 10 - 38 प67 प111

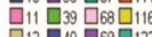

13041070132

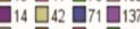

$215 \square 43 \square 74-150$

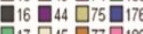

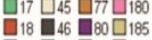

$19 \square 47 \square 82 \square 196$

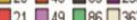

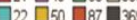

2301088

$24-52 \square 89 \square 554$

25 -53 $\square 90 \square 561$

$26 \square^{54} \square 93 \square 612$

$27-55 \square 94 \square 66$

Figure 1. Frequency distributions of data

Model Summary

\begin{tabular}{|l|l|}
\hline Algorithm & TwoStep \\
\hline Inputs & 4 \\
\hline Clusters & 2 \\
\hline
\end{tabular}

\section{Cluster Quality}

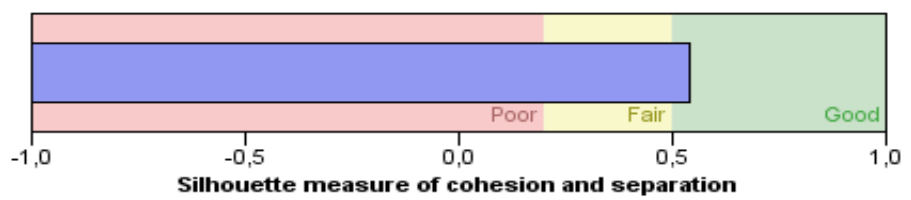

Figure 2. Frequency distributions of data 
Bilge International Journal of Science and Technology Research, 2020, 2 (Special Issue), 33-39

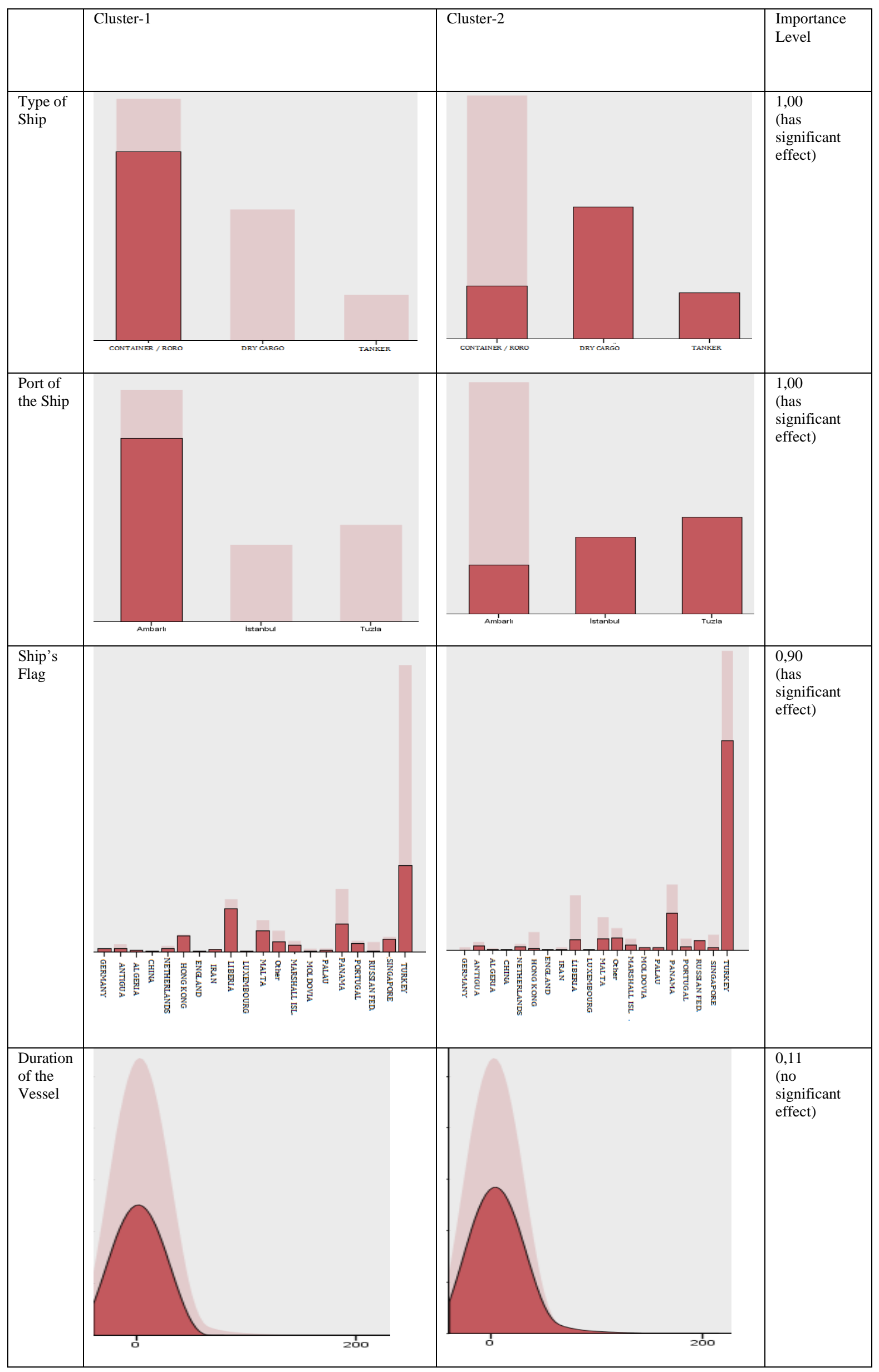

Figure 3. Clusters obtained by two-Stage clustering method 


\section{RESULTS}

At this stage, the ship profiles in the two clusters obtained in the analysis are explained generally. The interpretation of the clusters will be based on the type of ships, their flags, the length of their stay in the port and port of call.

As shown in Figure 4, the type of the vessel was significant in both clusters. While the first cluster is comprised of $100 \%$ container / ro-ro vessels, the second cluster also includes dry cargo vessels $(57.1 \%)$.

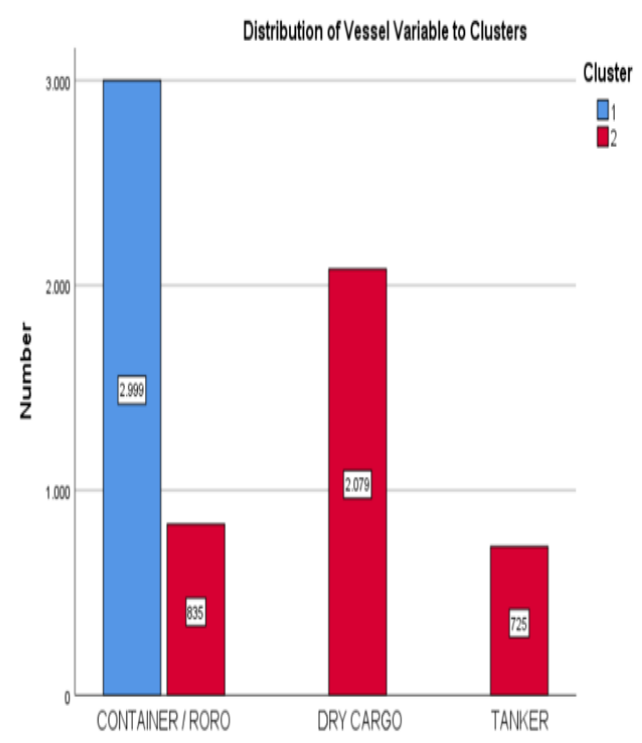

\begin{tabular}{|l|l|l|}
\hline & Cluster 1 & Cluster 2 \\
\hline Importance Level & 1,00 & 1,00 \\
\hline Container/Roro & 2999 & 835 \\
\hline Dry Cargo & 0 & 2079 \\
\hline Tanker & 0 & 725 \\
\hline
\end{tabular}

Figure 4. Distribution of vessel variable to clusters

When the port variable in which ships stayed is considered, it is seen that it has a significant effect on both clusters as in Figure 5. The first cluster is only comprised of the vessels staying at the port of Ambarl1 (100\%), while the second cluster mainly consists of the vessels stayed at the port of Tuzla (43.5\%).

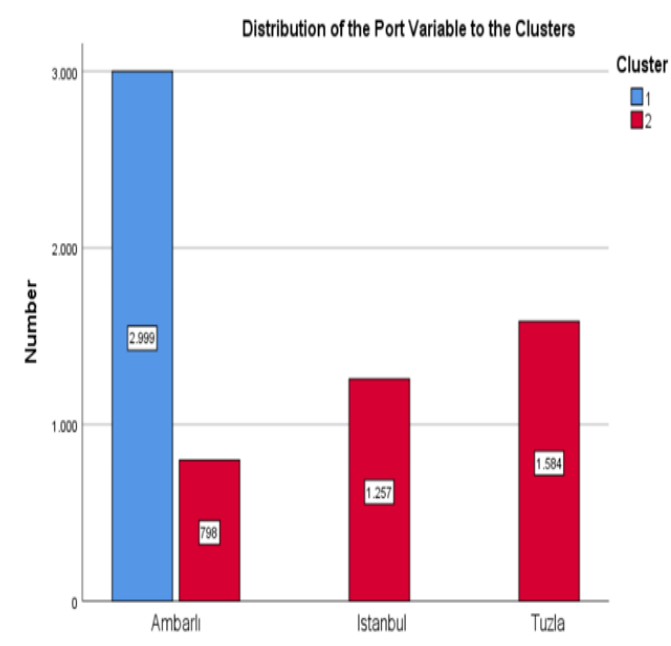

\begin{tabular}{|l|l|l|}
\hline & Cluster 1 & Cluster 2 \\
\hline Importance Level & 1,00 & 1,00 \\
\hline Ambarl| & 2999 & 798 \\
\hline Istanbul & 0 & 1257 \\
\hline Tuzla & 0 & 1584 \\
\hline
\end{tabular}

Figure 5. Distribution of the port variable to the clusters

When the distribution of the flag variable in clusters is examined, it is understood that it has significant effect in both clusters as seen in Figure 6. In both clusters, Turkish flagged vessels are a majority with $34.9 \%$ and $67.1 \%$ respectively. This group is followed by Liberian flagged ships in the first cluster and Panama flagged ships in the second cluster. It is seen that other flagged vessels are less likely to visit Istanbul Port Area. Accordingly, Turkish flagged ships are seen as an important variable among the ships that visited the Istanbul Port Region. 


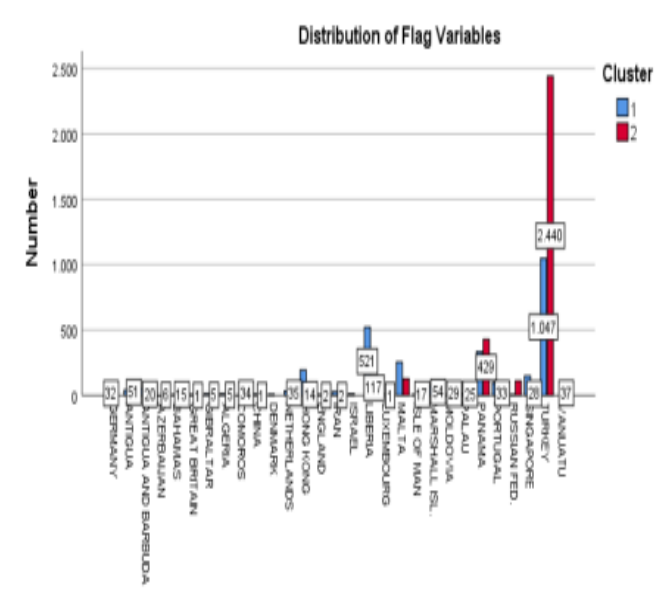

\begin{tabular}{|c|c|c|}
\hline & Cluster 1 & Cluster 2 \\
\hline Impertance Level & 0,90 & 0,90 \\
\hline Germany & 32 & 0 \\
\hline Antigua & 41 & 51 \\
\hline Antigua and Barbuda & 56 & 20 \\
\hline Azerbajajan & 2 & 6 \\
\hline Bahamas: & 8 & 15 \\
\hline Great Britain & 8 & 1 \\
\hline Gipraltar, & 15 & 5 \\
\hline Algeria & 15 & 5 \\
\hline Comoros & 3 & 34 \\
\hline China, & 10 & 1 \\
\hline Denmark & 9 & 0 \\
\hline Netherdands, & 34 & 35 \\
\hline Hong Kong & 194 & 14 \\
\hline England & 8 & 2 \\
\hline Iran & 29 & 2 \\
\hline Israel, & 12 & 0 \\
\hline biberia & 521 & 117 \\
\hline Luxembourg & 10 & 1 \\
\hline Malta & 254 & 128 \\
\hline ske, of Man & 7 & 17 \\
\hline Marshall |k | & 76 & 54 \\
\hline Meldexiaz & 6 & 29 \\
\hline Palau & 13 & 25 \\
\hline
\end{tabular}

Figure 6. Distribution of flag variables

When the length of stay of the vessels in various ports of Istanbul Port Area is examined as seen in Figure 7, it was found that the significance level of this variable in both clusters was around 0.11 , and it did not have a significant effect on cluster distribution. Therefore, this variable was ignored during the final stage of cluster properties.

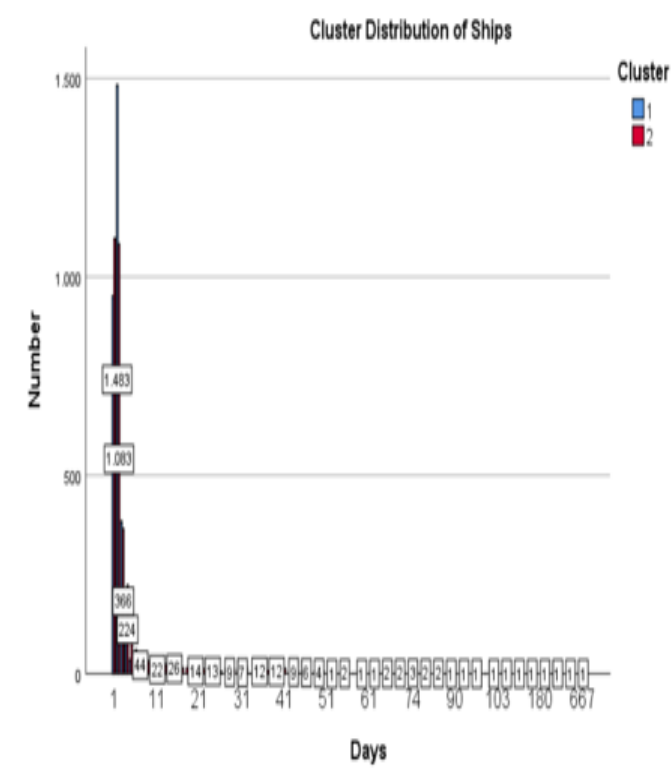

\begin{tabular}{|l|l|l|}
\hline & Cluster 1 & Cluster 2 \\
\hline Importance Level & 0,11 & 0,11 \\
\hline
\end{tabular}

Figure 7. Cluster distribution of ships

\section{DISCUSSION AND CONCLUSIONS}

In this study, the analysis of the ships in the ports in the Istanbul Port Area was carried out and a two-stage clustering analysis was conducted regarding the different characteristics of the ships in the ports. Cluster distributions were carried out according to the type of ships, flags, port of call and the length of stay in the ports. Accordingly, two clusters were formed and it was observed that the type, flag and the port variables of the vessels had significant effects on the clusters, while the length of stay in the ports did not have a significant effect on the clusters. Among the variables that affect the clusters significantly, the type and flag of the ship has the greatest importance level (1.00), while the port variable they stay in is the second regarding importance level (0.90). All variables are of equal importance for both sets.

The results of the analyses suggest that the first cluster was comprised of Container / Ro-ro type vessels that visited the port of Ambarl1, while the second group consisted of Turkish flagged, dry cargo type vessels that came to the port of Tuzla. According to the results obtained, the ships that came to Istanbul Port Area were categorized. The categorization indicated which type and which flagged vessels were visited the ports in Istanbul Port Area the most. For the entrepreneurs, who wish to invest in the port sector in Istanbul region, the ship profiles that make calls to this region constitute an important preliminary information for the investment.

Consequently, the commercially significant Istanbul Port Region is dominant with the characteristics specified for the two clusters, and the entrepreneurs who would invest will examine the empty spots based on these characteristics. In addition to the analysis conducted in this study, increasing market awareness, connection with $\mathrm{R} \& \mathrm{D}$ institutes, strategic cooperation operations and related maritime 
activities should be considered as other aspects for multimodal transport planning.

\section{ACKNOWLEDGEMENTS}

The author would like to thank the responsible reviewers and editors for their constructive feedback.

\section{REFERENCES}

Chang, Y. C. (2011). Maritime clusters: What can be learnt from the South West of England, Ocean \& Coastal Management, Volume 54, Issue 6, Pages 488-494, ISSN 0964-5691,

https://doi.org/10.1016/j.ocecoaman.2011.03.005.

Ceylan, Z., Gürsev, S., Bulkan, S. (2017). İki aşamalı kümeleme analizi ile bireysel emeklilik sektöründe müşteri profilinin değerlendirilmesi, Bilişim Teknolojileri Dergisi, Cilt: 10, Say1: 4, Ekim, DOI: 10.17671/gazibtd.323951

Guadalupe Arredondo-Hidalgo, M. \& Guadalupe Covarrubias Gardia, M. (2019). Automotive Cluster and Territorial Development: The Case of Bajio in Guanajuato Mexico, Paper presented in the 23rd Annual Western
Hemispheric Trade Conference, 3-5 April 2019, Texas A\&M International University A. R. Sanchez, Jr. School of Business Center for the Study of Western Hemispheric Trade.

Jain, U., Singh, M., Rishiraj, Verma, R., Vijay, R. \& Rastogi, R. (2019). Revision of PV2 based pedestrian crossing warrants in India using clustering techniques, Transportation Letters, $\quad 11: 5, \quad 241-249, \quad$ DOI: 10.1080/19427867.2017.1415122.

Saneinejad, S. \& Roorda, M. (2009). Application of sequence alignment methods in clustering and analysis of routine weekly activity schedules, Transportation Letters, 1:3, 197-211, DOI: 10.3328/TL.2009.01.03.197-211.

URL-1, İstanbul Liman Başkanlığı. < http://www.istanbulliman.gov.tr/>

Zhang, W. \& Lam, J. S. L. (2013). Maritime cluster evolution based on symbiosis theory and Lotka-Volterra model, Maritime Policy \& Management, 40:2, 161-176, DOI: $10.1080 / 03088839.2012 .757375$ 